\title{
Multiple pituitary hormone deficiency: beware of combined hormones deficiency
}

\author{
Nur Rochmah*, Muhammad Faizi, Achmad Yuniari, Netty Harjantien \\ From 7th APPES Biennial Scientific Meeting \\ Nusa Dua, Bali. 14-17 November 2012
}

Multiple Pituitary Hormone Deficiency (MPHD) is an endocrine disorder due to combination of pituitary hormones deficiencies. Clinical manifestations vary due to the combination of individual hormone deficiencies. The diagnosis is established based on history, signs and symptoms, hormonal and radiological examination. MPHD should be managed by hormones replacement according hormone abnormalities. The objective is to present a case of multiple pituitary hormones deficiency in a child, focusing in diagnosis and management.

A 14 years-old boy, come with main complaint of short stature and delayed puberty. The height was below the $3^{\text {rd }}$ percentile for age. Patient also suffered from micropenis. Tanner stage was prepuberta. Laboratories showed peak stimulated growth hormone concentration test was below $10 \mathrm{ng} / \mathrm{mL}$, low levels of IGF 1 and IGF-BP3; FT4: 5.99ng/ $\mathrm{dl}$ (normal:4.6-11),TSH: $3.08 \mathrm{IU} / \mathrm{mL}$ (normal:0.4-7.0); non stimulated LH level: $0.23 \mathrm{mIU} / \mu \mathrm{L}$ (cut-off limit prepubertal-pubertal level was $0.6 \mathrm{IU} / \mathrm{L}$ ), FSH: $1.6 \mathrm{mIU} / \mu \mathrm{L}$; testosrone: $<15 \mathrm{ng} / \mathrm{dL}$ (normal basal testosterone: $19 \mathrm{ng} / \mathrm{L}$ ). Working diagnosis was GH deficiency and hypogonadotrophic hypogonadism. This patient treated with growth hormone and testosterone. The height increased $10 \mathrm{~cm}$ during 10 months growth hormone treatment and the penile length increased became normal range. This paper reported growth hormone deficiencies accompanied by hypogonadotrophic hypogonadism. Facing patient with pituitary hormone deficiency must be aware of the abnormality of other pituitary hormone.

Published: 3 October 2013

Department of Child Health,School of Medicine, Airlangga University-Dr. Soetomo Hospital, Surabaya, Indonesia

(c) 2013 Rochmah et al; licensee BioMed Central Ltd. This is an Open Access article distributed under the terms of the Creative Commons Attribution License (http://creativecommons.org/licenses/by/2.0), which permits unrestricted use, distribution, and reproduction in any medium, provided the original work is properly cited.
doi:10.1186/1687-9856-2013-S1-P198

Cite this article as: Rochmah et al:: Multiple pituitary hormone deficiency: beware of combined hormones deficiency. International Journal of Pediatric Endocrinology 2013 2013(Suppl 1):P198.

Submit your next manuscript to BioMed Central and take full advantage of:

- Convenient online submission

- Thorough peer review

- No space constraints or color figure charges

- Immediate publication on acceptance

- Inclusion in PubMed, CAS, Scopus and Google Scholar

- Research which is freely available for redistribution 